\title{
Distribution of cell adhesion molecules in skeletal muscle from patients with systemic lupus erythematosus
}

\author{
M Pallis, D K Robson, D O Haskard, R J Powell
}

\begin{abstract}
Objective-To investigate the pathophysiology of perivascular mononuclear cell infiltrates observed in skeletal muscle from patients with systemic lupus erythematosus (SLE).

Methods-Immunocytochemical techniques were used to examine frozen $5 \mu \mathrm{m}$ sections from the quadriceps needle muscle biopsy specimens of 14 patients with SLE (including seven with infiltrates) for the expression of the cytokine inducible adhesion molecules intercellular adhesion molecule 1 (ICAM-1), vascular cell adhesion molecule-1 (VCAM-1), and E-selectin.

Results-Vessels in 6/7 SLE biopsy specimens with perivascular infiltrates expressed VCAM-1 at a density of $>2$ vessels $/ \mathrm{mm}^{2}$ in contrast with $0 / 7$ SLE biopsy specimens without infiltrates and $1 / 6$ control specimens. In contrast, E-selectin expression was increased $(>0.3$ positive vessels $/ \mathrm{mm}^{2}$ ) in SLE biopsy specimens compared with control tissue regardless of the presence of perivascular infiltration. VCAM-1 and ICAM-1 were also noted on extravascular cells in the infiltrates, being particularly prominent on the intermuscle fibre dendritic processes of CD68+ HLA-DR+ cells.

Conclusion-Expression of these cytokine inducible adhesion molecules may be important in the migration of mononuclear cells into skeletal muscle and may be involved in intercellular interactions within the tissue.
\end{abstract}

Department of

Immunology,

University Hospital,

Nottingham NG7 2UH,

United Kingdom

$M$ Pallis

R J Powell

Department of

Histopathology,

University Hospital,

Nottingham NG7 2UH,

United Kingdom

D K Robson

Department of

Medicine,

Hammersmith

Hospital, London

W12 0NN, United

Kingdom

D O Haskard

Correspondence to:

Dr Powell.

Accepted for publication

12 May 1993
(Ann Rheum Dis 1993; 52: 667-671)

Perivascular mononuclear cell infiltrates in skeletal muscle are common in systemic lupus erythematosus (SLE), being identified in all cases at necropsy. ${ }^{1}$ We noted that perivascular lymphocytic infiltrates in SLE muscle are associated with swelling of endothelial cells but, in contrast with polymyositis, are rarely accompanied by fibre necrosis or phagocytosis. ${ }^{2}$ The pathophysiological significance of mononuclear cell infiltrates in SLE muscle remains unclear and possibly they represent areas of focal vasculitis.

The emigration of leucocytes into inflammatory tissue depends in part upon the expression of appropriate leucocyte adhesion molecules on the surface of endothelial cells. ${ }^{3-5}$ Of these, intercellular adhesion molecule-1
(ICAM-1), vascular cell adhesion molecule-1 (VCAM-1), and E-selectin (previously designated ELAM-1) are each induced or upregulated by the cytokines interleukin- 1 and tumour necrosis factor, providing a mechanism for the amplification of the inflammatory response. Although the expression of E-selectin is thought to be restricted to cytokine activated endothelial cells, ICAM-1 and VCAM-1 are also found on a variety of cells within the tissues. ${ }^{6} 7$

The presence or absence of E-selectin, ICAM-1, and VCAM-1 provides an indication of their role in the formation of inflammatory infiltrates and also gives indirect evidence of the influence of cytokines. We used monoclonal antibodies against these three molecules to characterise further the mononuclear cell infiltrates found in skeletal muscle in SLE.

\section{Materials and methods}

As part of a continuing programme of research into muscle disease in SLE we investigated needle quadriceps muscle biopsy specimens from 14 patients with SLE, 11 with clinically active disease but without symptoms of muscle involvement or raised creatine kinase, and three with clinical muscle weakness (patients 1 , 4, 13-see table 1). Thirteen of 14 patients fulfilled at least four of the 1982 American Rheumatism Association (ARA) revised criteria for SLE. ${ }^{8}$ (One patient had only three ARA criteria for SLE, and the diagnosis of SLE was based on digital vasculitis, vasculitic leg ulcers, polymyositis, Raynaud's phenomenon, telangiectasia, antinuclear antibody titre of $1 / 3200$, and antibodies to RNP.) Including this last patient, six people in our study (patients 4, $7,8,9,11$, and 13) could also be considered to have mixed connective tissue disease based on the presence of Raynaud's phenomenon and an antinuclear antibody titre of at least $1 / 800$, together with the presence of antibodies to RNP in the absence of either antibodies to $\mathrm{Sm}$ or antibodies to dsDNA. The term mixed connective tissue disease, however, has not gained full acceptance and consequently all study patients were grouped under the diagnosis of SLE. Table 1 provides clinical information on the patients.

Control muscle was available from six further patients: three with non-specific mild muscle symptoms and three who were undergoing surgery on the pituitary fossa for prolactinoma or non-secretory adenoma and required removal of quadriceps muscle to fill 
Table 1 Clinical information

\begin{tabular}{|c|c|c|c|c|c|c|c|c|c|c|c|c|}
\hline $\begin{array}{l}\text { Patient } \\
\text { No }\end{array}$ & Sex & $\begin{array}{l}\text { Diagnosis } \\
\left(A R A^{\star}\right. \\
\text { criteria } \\
\text { fulfilled })\end{array}$ & $M C T D^{*}$ & $\begin{array}{l}\text { Age at } \\
\text { biopsy } \\
\text { (years) }\end{array}$ & $\begin{array}{l}\text { Disease duration } \\
\text { to biopsy (years) }\end{array}$ & Treatment * & $\begin{array}{l}\text { Clinical features } \\
\text { at time of biopsy }\end{array}$ & $\begin{array}{l}\text { C3d† } \\
(U / \mathrm{ml})\end{array}$ & $\begin{array}{l}E S R^{\star}+ \\
(\mathrm{mm} / \mathrm{h})\end{array}$ & $\begin{array}{l}C K \\
(I U /)\end{array}$ & $\begin{array}{l}\text { Indications } \\
\text { for biopsy }\end{array}$ & $\begin{array}{l}\text { Muscle biopsy } \\
\text { findings }\end{array}$ \\
\hline 1 & $\mathrm{~F}$ & 4 & - & 48 & 2 & Aza & $\begin{array}{l}\text { Pleurisy } \\
\text { Malaise }\end{array}$ & 5 & 66 & 30 & $\begin{array}{l}\text { Proximal and } \\
\text { distal weakness } \\
\text { in legs }\end{array}$ & $\begin{array}{c}\text { Perivascular } \\
\text { infiltrate }\end{array}$ \\
\hline 2 & $\mathrm{~F}$ & 4 & - & 54 & 7 & HCA & $\begin{array}{l}\text { Polyarthritis } \\
\text { Pleuropericarditis }\end{array}$ & 21 & 62 & 283 & $\begin{array}{l}\text { Active disease } \\
\text { No muscle } \\
\text { symptoms }\end{array}$ & $\begin{array}{l}\text { Perivascular } \\
\text { infiltrate with } \\
\text { mild fibre } \\
\text { necrosis }\end{array}$ \\
\hline 3 & $\mathbf{F}$ & 7 & - & 25 & 4 & $\begin{array}{l}\text { HCA } \\
\text { Aza } \\
\text { Pred }\end{array}$ & Polyarthralgia & 12 & 2 & 28 & $\begin{array}{l}\text { Disease } \\
\text { assessment } \\
\text { No muscle } \\
\text { symptoms }\end{array}$ & Normal \\
\hline 4 & $\mathrm{~F}$ & 4 & + & 44 & 6 months & $\begin{array}{l}\text { Pred } \\
\text { Aza }\end{array}$ & $\begin{array}{l}\text { Malaise } \\
\text { Mouth ulcers }\end{array}$ & 8 & 18 & 1265 & $\begin{array}{l}\text { Myalgia and } \\
\text { muscle } \\
\text { weakness }\end{array}$ & $\begin{array}{l}\text { Resolving } \\
\text { polymyositis }\end{array}$ \\
\hline 5 & $\mathrm{~F}$ & 5 & - & 58 & 10 & $\mathrm{HCA}$ & $\begin{array}{l}\text { Malaise } \\
\text { Bruising }\end{array}$ & 13 & 22 & 44 & $\begin{array}{l}\text { Investigation of } \\
\text { malaise }\end{array}$ & $\begin{array}{l}\text { No perivascular } \\
\text { infiltrate } \\
\text { Type IIB fibre } \\
\text { atrophy }\end{array}$ \\
\hline 6 & $\mathrm{~F}$ & 5 & - & 20 & 4 & NSAID & $\begin{array}{l}\text { Mouth ulcers } \\
\text { Polyarthritis }\end{array}$ & 19 & 39 & 120 & $\begin{array}{l}\text { Investigation of } \\
\text { disease } \\
\text { Marked early } \\
\text { morning } \\
\text { stiffness }\end{array}$ & $\begin{array}{l}\text { Perivascular } \\
\text { infiltrate } \\
\text { Type IIB fibre } \\
\text { atrophy }\end{array}$ \\
\hline 7 & $\mathbf{F}$ & 5 & + & 73 & 2 months & NSAID & Polyarthralgia & 8 & 15 & 51 & $\begin{array}{l}\text { Disease } \\
\text { assessment }\end{array}$ & $\begin{array}{l}\text { Perivascular } \\
\text { infiltrate } \\
\text { Type IIB fibre } \\
\text { atrophy }\end{array}$ \\
\hline 8 & $\mathbf{F}$ & 4 & + & 69 & 5 & Pred & $\begin{array}{l}\text { Polyarthralgia } \\
\text { Joint stiffness }\end{array}$ & 10 & 33 & 58 & $\begin{array}{l}\text { Disease } \\
\quad \text { assessment }\end{array}$ & Normal \\
\hline 9 & $\mathbf{F}$ & 3 & + & 42 & 10 & Nil & Vasculitic leg ulcers & 8 & 10 & 71 & $\begin{array}{l}\text { No muscle } \\
\text { symptoms or } \\
\text { weakness }\end{array}$ & $\begin{array}{l}\text { Active low grade } \\
\text { myositis } \\
\text { No perivascular } \\
\text { infiltrate }\end{array}$ \\
\hline 10 & $\mathrm{~F}$ & 4 & - & 38 & 2 & $\begin{array}{l}\text { HCA } \\
\text { NSAID }\end{array}$ & $\begin{array}{l}\text { Pleurisy } \\
\text { Polyarthritis } \\
\text { Depersonalisation }\end{array}$ & 20 & 97 & $<20$ & $\begin{array}{l}\text { Disease } \\
\text { assessment } \\
\text { Muscle } \\
\text { tenderness }\end{array}$ & $\begin{array}{l}\text { Perivascular } \\
\text { infiltrate }\end{array}$ \\
\hline 11 & $\mathrm{~F}$ & 4 & + & 62 & 6 & NSAID & Polyarthralgia & 10 & 18 & 52 & Tiredness & Normal \\
\hline 12 & F & 4 & - & 43 & 3 & Pred & Cerebral SLE & 8 & 24 & 92 & $\begin{array}{l}\text { Disease } \\
\text { assessment }\end{array}$ & Normal \\
\hline 13 & $\mathbf{F}$ & 4 & + & 41 & 3 & $\begin{array}{l}\text { Pred } \\
\text { Aza }\end{array}$ & $\begin{array}{l}\text { Muscle tiredness } \\
\text { Malaise }\end{array}$ & 10 & 25 & 2600 & Muscle weakness & $\begin{array}{l}\text { Polymyositis with } \\
\text { perivascular } \\
\text { cuffing }\end{array}$ \\
\hline 14 & $\mathrm{~F}$ & 4 & - & 25 & 6 months & $\begin{array}{l}\text { Pred } \\
\text { Cyclo }\end{array}$ & Cerebral disease & 13 & 43 & 120 & $\begin{array}{l}\text { Disease } \\
\text { assessment-no } \\
\text { myalgia }\end{array}$ & $\begin{array}{l}\text { Type IIB atrophy } \\
\text { Occasional } \\
\text { scatterd } \\
\text { lymphocytes }\end{array}$ \\
\hline
\end{tabular}

*ARA=American Rheumatism Association; MCTD=mixed connective tissue disease; Aza=azathioprine; HCA=hydroxychloroquine; Pred=prednisolone; NSAID=non-steroidal anti-inflammatory drug; Cyclo=cyclophosphamide; $E S R=$ erythrocyte sedimentation rate; $C K=$ creatine kinase.

NNAID=non-steroidal anti-inflammatory drug; Cyclo=cyclophosph

the pituitary fossa. In all the control subjects the histology had been reported as normal after inspection of serial sections stained both by haematoxylin and eosin (H\&E) and enzyme histochemical methods. ${ }^{9}$ Of the 14 patients with SLE, six (patients $1,2,6,7,10$, and 13-see table 1) demonstrated perivascular accumulation of lymphocytes and two of these (2 and 13), in addition, had marked fibre damage. A further patient (patient 9) had a low grade focal inflammatory infiltrate associated with necrotic and degenerate fibres but without perivascular infiltrates and another (patient 4) had a low grade muscle parenchymal infiltrate on routine histology, but the sections examined for this study seemed to be normal.

\section{MUSCLE BIOPSY}

Cores of vastus lateralis from the lateral midthigh were obtained under local anaesthesia with a $5 \mathrm{~mm}$ diameter Bergstrom percutaneous needle. They were wrapped in a damp saline gauze and transported rapidly to the laboratory. Here they were oriented transversely, embedded in OCT (Miles), and mounted on cork holders before being frozen in isopentane cooled in liquid nitrogen. After cutting cryostat sections for routine histology the remaining tissue was stored at $-70^{\circ} \mathrm{C}$.
IMMUNOCYTOCHEMICAL STAINING

Serial $5 \mu \mathrm{m}$ cryostat sections were positioned on poly-L-lysine coated glass slides. The first slide was stained with $\mathrm{H} \& \mathrm{E}$. The remaining slides were dried for 15 minutes at room temperature, fixed in cold acetone for 20 minutes, and redried for 15 minutes in a fan oven at ambient temperature. The slides were next covered and left at room temperature for up to 48 hours. Slides were preincubated in 1:5 normal swine serum in TRIS buffered saline (TBS) (pH 7.6) for 20 minutes. ${ }^{10}$ They were then incubated in primary antibody diluted in 1:20 normal swine serum in TBS for 30 minutes. Table 2 shows antibodies and dilutions. The antibodies to ICAM-1, VCAM1 , and E-selectin are described in reference 11. Normal swine serum, diluted 1:5, was used as the negative control. In five cases where examination of the $H \& E$ stain showed a lymphocytic inflammatory infiltrate the full panel of antibodies was used. In the remainder of cases only antibodies to cell adhesion molecules and leucocyte common antigen were used.

The staining order shown in table 2 for the serial sections was selected:

(a) To determine whether the endothelial cell adhesion molecule expression coincided with leucocyte infiltrates the sections reacting with 
Table 2 Antibodies and dilutions

\begin{tabular}{lll}
\hline Target antigen (antibody clone) & \\
\hline 1 & Intracellular adhesion molecule-1 (ICAM-1, CD54) (6-5B5) (ref 11) & Dilution \\
2 & Leucocyte common antigen (Dako PD7/2B11) & Undiluted \\
3 & E-selectin (ELAM-1) (1-2B6) (ref 11) & $1: 10$ \\
4 & Vascular cell adhesion molecule-1 (VCAM-1) (1·4C3) (ref 11) & Undiluted \\
5 & CD68 (Dako EBM-11) identifies mononuclear phagocytes & Undiluted \\
6 & CD3 (Dako 4B5), associated with the T cell antigen receptor & $1: 50$ \\
7 & HLA-DR (Dako), a class II histocompatibility antigen & $1: 5$ \\
8 & CD22 (Dako), a pan-B cell marker & $1: 50$ \\
\hline
\end{tabular}

Table 3 Number of vessels in each biopsy specimen staining for cell adhesion molecules

\begin{tabular}{|c|c|c|c|c|c|c|c|}
\hline \multirow[t]{2}{*}{ Group } & & \multicolumn{3}{|c|}{$\begin{array}{l}\text { VCAM-1 positive } \\
\text { vessels } / \mathrm{mm}^{2}\end{array}$} & \multicolumn{3}{|c|}{$\begin{array}{l}\text { E-selectin positive } \\
\text { vessels } / \mathrm{mm}^{2}\end{array}$} \\
\hline & & $\geqslant 0 \cdot 3$ & $\geqslant 1$ & $\geqslant 2$ & $\geqslant 0 \cdot 3$ & $\geqslant 1$ & $\geqslant 2$ \\
\hline 1 & Normal controls & $4 / 6$ & $4 / 6$ & $1 / 6$ & $1 / 6$ & $0 / 6$ & $0 / 6$ \\
\hline 2 & $\begin{array}{l}\text { SLE muscle sections with } \\
\text { lymphocytic infiltrates }\end{array}$ & $6 / 7$ & $6 / 7$ & $6 / 7$ & $6 / 7$ & $2 / 7$ & $1 / 7$ \\
\hline 3 & $\begin{array}{l}\text { SLE muscle sections without } \\
\text { lymphocytic infiltrates }\end{array}$ & $6 / 7$ & $2 / 7$ & $0 / 7$ & $5 / 6^{\star}$ & $0 / 6$ & $0 / 6$ \\
\hline 1 and 2 & Comparison using Fisher's exact test & - & - & $p=0.02$ & $p=0.02$ & - & - \\
\hline 2 and 3 & Comparison using Fisher's exact test & - & - & $\mathrm{p}=0.002$ & $p=0.54$ & - & - \\
\hline 1 and 3 & Comparison using Fisher's exact test & - & - & $\mathrm{p}=0.46$ & $\mathrm{p}=0.04$ & - & - \\
\hline
\end{tabular}

$\star$ E-selectin not done on one patient.

antibodies to cell adhesion molecules were grouped around the section reacting with antibodies to leucocyte common antigen.

(b) To indicate whether $\mathrm{T}$ cells within the lesion were expressing HLA-DR, anti-HLADR was used on a section adjacent to the antiCD3 treated section.

(c) To demonstrate the approximate proportions of macrophages, $T$ cells, and $B$ cells in the lesions the antibodies to CD68, CD3, and CD22 were grouped together.

After incubation in the primary antiserum, sections were rinsed in TBS, $\mathrm{pH} 7 \cdot 6$, and incubated in a peroxidase conjugated secondary antiserum-namely, rabbit antimouse immunoglobulin (Dako), diluted 1:100, for 30 minutes. Sections were then rinsed in TBS and the peroxidase was visualised by incubation in $300 \mathrm{ml}$ of TBS, $\mathrm{pH} 7 \cdot 6$, containing $0.15 \mathrm{~g}$ of 3,3'-diaminobenzidine tetrahydrochloride (Fluka), 0.2 g of imidazole (Sigma), and 225 $\mu l$ of $6 \%$ hydrogen peroxide for 10 minutes. Sections were then rinsed, lightly post-stained in haematoxylin, and mounted. All the above procedures were carried out at room temperature.

The total number of vessels positive for E-selectin and VCAM-1 was recorded from examination of the entire section at $100 \times$ magnification. The area of the sections stained for E-selectin and VCAM-1 was calculated with computer aided image analysis equipment (Seescan) to allow calculation of the density of positively staining vessels. Comparisons between groups were made using Fisher's exact probability test.

\section{Results}

We compared the distribution of adhesion molecules in the muscle biopsy specimens of patients with SLE and those of control subjects. Slides stained with $H \& E$ and with leucocyte common antigen were examined to distinguish between perivascular and muscle parenchymal infiltration. Surface area of sections ranged between 2.5 and $10.5 \mathrm{~mm}^{2}$.

MICROVASCULAR EXPRESSION OF CELL ADHESION MOLECULES

In any one section all blood vessels with a perivascular infiltrate reacted with $1.4 \mathrm{C} 3$ antibody to VCAM-1 (fig 1A). Examination of each section as a whole showed that at least two vessels per $\mathrm{mm}^{2}$ reacted in six of seven patients with lymphocytic infiltrates (patients $1,2,6,7$, 9 , and 13) compared with one of six control patients $(p=0.025)$ and none of the seven patients without infiltrates $(p=0.0023$ ) (see table 3).

1.2B6 antibody against E-selectin was expressed on at least 0.3 vessels per $\mathrm{mm}^{2}$ (two or more vessels per section) in 11 of 13 patients with SLE (all except patients 3 and 10) and in one of six control patients. Compared with biopsy specimens from normal controls, there was significantly higher E-selectin expression on SLE biopsy specimens both with $(\mathrm{p}=0.0245)$ and without $(\mathrm{p}=0.039)$ lymphocytic infiltrates. Although all vessels with perivascular lymphocytic infiltrates reacted with anti-E-selectin, the intensity of expression on some vessels was low, and in contrast with VCAM-1 expression there was no significant difference in E-selectin expression between SLE biopsy specimens with and without lymphocytic infiltration $(p=0 \cdot 54)$.

As anticipated, ICAM-1 was widely expressed on vessels in control and SLE biopsy specimens. No attempt was made to measure


Figure 1 Muscle biopsy specimen from a patient with systemic lupus erythematosus (patient 6) showing a lymphocytic infiltrate surrounding an occluded small vessel. The non-infiltrated tissue on the upper right and on the left hand side of the field is muscle fibre. (A) VCAM-1 is expressed in the wall of the affected vessel and on some infiltrating cells at the bottom of the field; (B) ICAM-1 is expressed in the same vessel and infiltrate. Immunoperoxidase with haematoxylin counterstain. (Bound antibody illustrated by black staining.) Bar $=20 \mu \mathrm{m}$. 

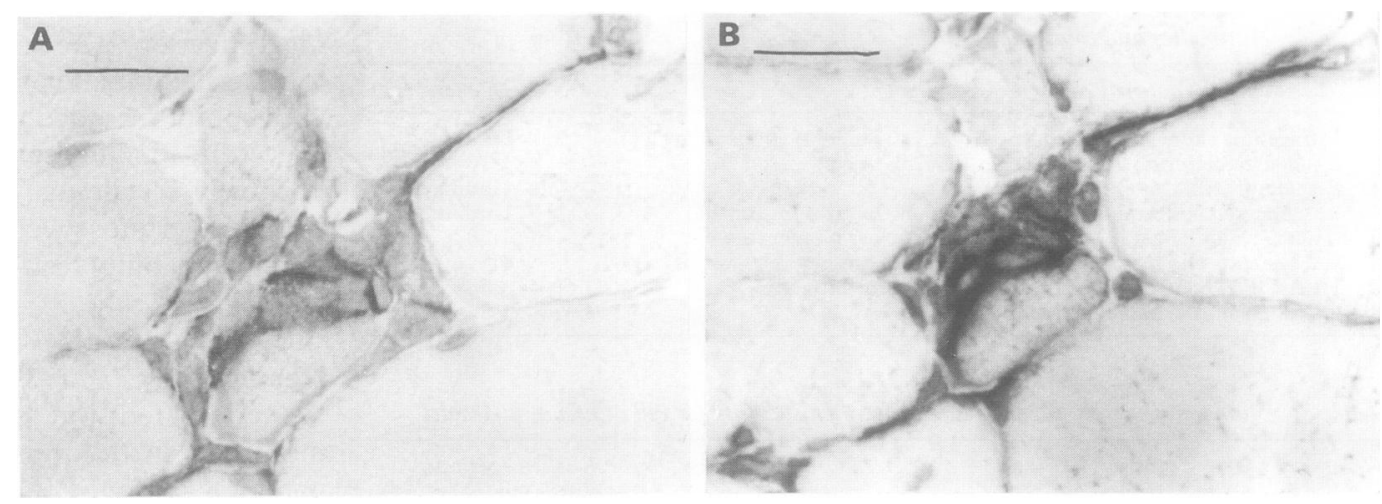

Figure 2 Muscle biopsy specimen from a patient with mixed connective tissue disease (patient 13). The central muscle fibre is infiltrated by mononuclear cells. (A) VCAM-1 and (B) ICAM-1 are expressed on cells within the infiltrate and on interfibre dendritic processes. Immunoperoxidase with haematoxylin counterstain. (Bound antibody illustrated by black staining.) $B a r=20 \mu m$.

ICAM-1 expression, though there was a visibly increased intensity of staining on vessels with perivascular infiltrates (fig 1B) compared with unaffected vessels of patients with infiltrates.

EXTRAVASCULAR EXPRESSION OF CELL

ADHESION MOLECULES

No extravascular expression of E-selectin was noted in the muscle of patients with SLE or controls. Extravascular staining with antiVCAM-1 was found in conjunction with the larger inflammatory infiltrates. In some areas its expression was amorphous and might have been associated with necrotic tissue. A striking observation was of fine interfibre dendritic processes reacting with antibody to VCAM-1 (fig 2A) in all three cases with muscle parenchymal infiltrates (patients 2, 9, and 13). These processes were most concentrated in apposition to necrotic muscle fibres and, based upon inspection of serial sections, also reacted with antibodies to ICAM-1, CD68, and HLADR. In all control and non-infiltrated muscle sections examined the number of distinct dendritic processes reacting with anti-VCAM1 was between zero and two. This also applied to three of the four patients with purely perivascular infiltrates. The fourth patient (patient 6) had antibody to VCAM-1 expressed on dendritic processes radiating from the affected vessel, but not elsewhere.

In contrast with VCAM-1, extravascular expression of ICAM-1 was noted on frequent, fine, interfibre dendritic processes in all control and patient samples (fig 3 ), though the number of ICAM-1 positive dendritic processes was

Figure 3 Normal muscle showing expression of ICAM-1 on interfibre processes. Immunoperoxidase with haematoxylin counterstain. hound antibody illustrated by black staining.) Bar $=20 \mu \mathrm{m}$. markedly increased in some patients with perivascular infiltrates and in all three patients (patients 2, 9, and 13) with muscle fibre involvement (fig 2B). ICAM-1 was also expressed on a small proportion of mononuclear inflammatory cells (fig 1B).

CELLULAR COMPOSITION OF INFILTRATES

Perivascular infiltrates were found to be composed predominantly of $\mathrm{CD} 3+$ and CD68+ cells. The infiltrates were mostly small, and therefore detailed quantitative analysis could not be performed. In the larger infiltrates (>50 cells per section-patients $1,2,13$ ), CD3 + cells outnumbered CD68+ cells by at least four to one. Only one or two cells in each infiltrate were CD22+ (B cells), except in one case (patient 2 ) where nearly $30 \%$ of cells were CD22+. No cells in any of the infiltrates showed the speckled peroxidase reactivity typical of granulocytes.

HLA-DR EXPRESSION ON T CELLS

In the sections with smaller infiltrates it was not clear whether CD3+ cells were also HLA$\mathrm{DR}+$, given that serial sections rather than double staining had been performed. In the three pairs of sections with the largest infiltrates, because most infiltrating cells were CD3+ and also HLA-DR+, one can conclude that these populations overlapped.

\section{Discussion}

We have characterised skeletal muscle biopsy specimens from patients with SLE for the expression of the cytokine inducible adhesion molecules ICAM-1, VCAM-1, and E-selectin. Examination of blood vessels showed expression of both VCAM-1 and E-selectin in biopsy specimens with mononuclear cell infiltration. Interestingly, the slight increase, compared with control biopsy specimens, in the numbers of vessels expressing E-selectin in SLE was not related to the presence of leucocytes in the tissues, whereas marked VCAM-1 expression by blood vessels $(\geqslant 2$ vessels $/ \mathrm{mm}^{2}$ ) was only seen in biopsy specimens with mononuclear cell infiltrates. This suggests that E-selectin expression may be a 
general feature of the skeletal muscle microvasculature in SLE, perhaps related to raised levels of circulating cytokines, though there is as yet little evidence of this. ${ }^{12}{ }^{13}$ In contrast, the data suggest that VCAM-1 expression is more likely to be determined by factors released locally by cells within perivascular infiltrates. Because of the high constitutive expression of ICAM-1 on vessels in normal skeletal muscle, no attempt was made to measure ICAM-1 expression, though like VCAM-1 expression, this seemed to be greatest on vessels with perivascular mononuclear cell infiltrates.

An increase of dendritic cells has been noted in a variety of chronic inflammatory disorders, including polymyositis, ${ }^{14}{ }^{15}$ and leucocyte common antigen positive, HLA-DR+, CD68+, acid phosphatase negative dendritic cells in muscle have recently been characterised in our laboratories (Lowe J, personal communication). We documented ICAM-1 both on control and SLE muscle dendritic cells, whereas the expression of VCAM-1 on dendritic cells was limited, with one exception, to those biopsy specimens in which parenchymal muscle infiltrates were present. This may denote de novo expression of VCAM-1, but it is recognised that immunoperoxidase is a relatively insensitive technique and that the use of other immunocytochemical methods might have indicated upregulation rather than de novo expression. ICAM-1 on accessory cells has been shown to be involved in $\mathrm{T}$ cell activation ${ }^{16} 17$ and our findings support the concept that dendritic cells have a significant role in $\mathrm{T}$ cell activation in chronic inflammatory disease. ${ }^{15}$ In vitro studies with purified VCAM-1 have suggested that it, too, may have an additional role in the costimulation of T cells. ${ }^{1819}$ VCAM-1 has also been identified on a population of extravascular stellate cells in inflamed, but not normal skin, ${ }^{720}$ a situation not dissimilar to our own findings in muscle.

Classically, immunoglobulin and complement deposition in muscle vessels has been regarded as evidence for an immune complex mediated pathogenesis of vessel damage in SLE. ${ }^{21}{ }^{22}$ We have shown, however, that the capillary lesions in SLE skeletal muscle contain a large proportion of HLA-DR+ T cells, and we note that similar findings have been recorded in the renal biopsy specimens from patients with SLE. ${ }^{23}$ Our results also show marked upregulation of ICAM-1 on round, closely associated inflammatory cells (fig 2). Upregulation of ICAM-1 is a feature of both antigen presenting cells and activated $T$ cells $^{24-26}$ and may be involved in $T$ cell cytotoxicity. ${ }^{27} 28$

In conclusion, we suggest that the three inducible adhesion molecules ICAM-1, VCAM-1, and E-selectin play a part in the pathogenesis of these microvascular inflammatory lesions in muscle in patients with SLE. Whether or not the perivascular infiltrates associated with small vessel endothelial swelling involve vascular injury is a question which must remain open.
1 Lowman E W. Muscle, nerve and synovial changes in lupus erythematosus. Ann Rheum Dis 1951; 10: 16-21.

2 Mastaglia F L, Walton Sir J. Skeletal Muscle Pathology. Edinburgh: Churchill Livingstone, 1982.

3 Pober J S, Cotran R. Cytokines and endothelial cell biology. Physiol Rev 1990; 70: 427-51.

4 Springer T A. Adhesion receptors of the immune system Nature 1990; 346: 425-34.

5 Shimizu Y, Newman W, Tanaka Y, Shaw S. Lymphocyte interactions with endothelial cells. Immunol Today 1992; 13: $106-12$.

6 Dustin M L, Rothlein R, Bhan A K, Dinarello C A, Springer $T$ A. Induction by IL-1 and interferon- $\gamma$ : tissue distribution, biochemistry and function of a natura adherence molecule (ICAM-1). F Immund 1986; 137 245-54.

7 Rice G E, Munro J M, Corless C, Bevilacqua M P. Vascular and non-vascular expression of INCAM-1 10. Am $\mathcal{F}$ Patho 1991; 138: 385-93.

8 Tan E M, Cohen A S, Fries J F, et al. The 1982 revised criteria for the classification of systemic lupus erythematosus. Arthritis Rheum 1982; 25: 1271-7.

9 Lowe J S, Stevens A, Powell R J. Detection of subclinical inflammatory involvement of muscle in connective tissue inflammatory involvement of muscle in connective

10 Lowe J, Maclennan K A, Powe D G, Pound J D, Palmer J B. Microglial cells in human brain have phenotypic characteristics related to possible function as dendritic antigen presenting cells. $\mathcal{F}$ Pathol 1989; 159: 143-9.

11 Wellicome S M, Thornhill M H, Pitzalis C, et al. A monoclonal antibody that detects a novel antigen on endothelial cells that is induced by tumour necrosis factor, IL-1 or lipopolysaccharide. f Immunol 1990; 144 2558-65.

12 Horwitz D A, Stohl W. T-lymphocytes, cytokines and immune regulation in systemic lupus erythematosus. In: D J Wallace, B H Hahns, eds. Dubois' lupus erythematosus 4th ed. Philadelphia: Lea and Febiger, 1993: 89-91.

13 Maury C P J, Teppo A-M. Tumour necrosis factor in the serum of patients with systemic lupus erythematosus. serum of patients with systemic
Arthritis Rheum 1989; 32: 146-50.

14 Rowe D J, Isenberg D A, Beverley P C L. Monoclonal antibodies to human leukocyte antigens in polymyositis and muscular dystrophy. Clin Exp Immunol 1983; 54 327-36.

15 Poulter L W, Janossy G. Involvement of dendritic cells in chronic inflammatory disease. Scand $\mathcal{F}$ Immunol 1985; 21 401-7.

16 Altman D M, Hogg N, Trowsdale J, Wilkinson D Cotransfection of ICAM-1 and HLA-DR reconstitutes human antigen-presenting cell function in mouse $L$ cells. Nature 1989; 338: 512-4.

17 Dransfield I, Buckle A-M, Hogg N. Early events of the immune response mediated by leukocyte integrins. immune response mediated

18 van Seventer G A, Newman W, Shimizu Y, et al. Analysis of $\mathrm{T}$ cell stimulation by superantigen plus majo histocompatibility complex class II molecules or by CD monoclonal antibody: costimulation by purified adhesio ligands VCAM-1, ICAM-1, but not ELAM-1. f Exp Me 1991; 174: 901-13.

19 Damle N K, Klussman K, Linsley P S, Aruffo A Differential costimulatory effects of adhesion molecules B7, ICAM-1, LFA-3, and VCAM-1 on resting and antigen-primed CD4+ T lymphocytes. $f$ Immunol 1992; 148: 1985-92.

20 Norris P, Poston R N, Thomas D S, Thornhill M, Hawk $\mathrm{J}$, Haskard D O. The expression of endothelial leukocyte , Haskard D O. The expression of endothelial leukocyte molecule-1 (ICAM-1) and vascular cell adhesion molecule-1 (ICAM-1) and vascular cell adhesion
molecule-1 (VCAM-1) in experimental cutaneous molecule-1 (VCAM-1) in experimental cutaneous delayed hypersensitivity. $\mathcal{F}$ Invest Dermatol 1991; 96: 763-70.

21 Whitaker J N, Engel W K. Vascular deposits of immunoglobin and complement in idiopathic inflammatory myopathy. $N$ Engl $f$ Med 1972; 286: 333-8.

22 Oxenhandler $R$, Adelstein $E$ H, Hart $M \quad N$. Immunopathology of skeletal muscle. Hum Pathol 1977; 8: $321-8$

23 Caligaris-Cappio F, Bergui L, Tesio L, Ziano R, Camussi G. HLA-DR+ T cells of the Leu 3 (helper) type infiltrate G. HLA-DR+ T cells of the Leu 3 (helper) type infiltrate erythematosus. Clin Exp Immunol 1985; 59: 185-9.

24 Dougherty G J, Murdoch S, Hogg N. The function of human intercellular adhesion molecule-1 (ICAM-1) in the generation of an immune response. Eur $\mathcal{f}$ Immunol 1988; 18: 35-9.

25 Buckle A-M, Hogg N. Human memory T cells express intercellular adhesion molecule-1 which can be increased by interleukin 2 and interferon- $\gamma$. Eur 7 Immunol 1990; 20: $337-41$.

26 Geissler D, Gaggl S, Most J, Greil R, Herold M, Dierich M. A monoclonal antibody directed against the human intercellular adhesion molecule (ICAM-1) modulates the release of tumour necrosis factor- $\alpha$, interferon- $\gamma$ and release of tumour necrosis factor- $\alpha$, interfer

27 Boyd A W, Wawryk S O, Burns G F, Fecondo J V. Intercellular adhesion molecule 1 (ICAM-1) has a central Intercellular adhesion molecule 1 (ICAM-1) has a central
role in cell-cell contact-mediated immune mechanisms. role in cell-cell contact-mediated immune

28 Wang P, Vanky F, Li S-L, Patarroyo M, Klein E. Functional characteristics of the intercellular adhesion molecule-1 characteristics of the intercellular adhesion molecule-1 lymphocytes. Cell Immunol 1990; 131: 366-80. 